Article

\title{
Cassava Waste Management and Biogas Generation Potential in Selected Local Government Areas in Ogun State, Nigeria
}

\author{
David O. Olukanni *(D) and Tope O. Olatunji \\ Department of Civil Engineering, College of Engineering, Covenant University, Ota 121101, Ogun State, Nigeria; \\ engrolatunji@yahoo.com \\ * Correspondence: david.olukanni@covenantuniversity.edu.ng
}

Received: 5 September 2018; Accepted: 12 December 2018; Published: 14 December 2018

check for updates

\begin{abstract}
Agricultural products such as cassava produce huge amounts of waste when processed into consumable goods. The waste generated is generally considered to contribute largely to environmental pollution. This study therefore investigates the waste management practice that is adopted by cassava processors in Ogun State, Nigeria. Five local government areas (LGAs) dominant in processing cassava were selected for the study on the basis of spatial location distribution, landmass, and population. The survey involved the use of structured questionnaires administered to cassava processors of the selected LGAs. The Statistical Package for Social Sciences (SPSS) software application and descriptive statistics were used for data analysis. Results of the analysis show that the majority $(70 \%)$ of the cassava processors are females. Cassava peel constitutes $10 \%$ of the waste produced, of which $91 \%$ is heaped at refuse dumps in most communities. Results also reveal that $86.3 \%$ of cassava residues are used for animal feeds. Other findings show that the peels, when dried, are used as biofuel for cooking and there is a significant potential for biogas production. From the data captured from respondents during the study, most processors are willing to pay for an improved waste management system. The study therefore recommends the proper waste management of cassava waste to minimize environmental pollution.
\end{abstract}

Keywords: solid waste management; environmental pollution; agricultural waste; cassava waste; biogas generation; sustainable technology

\section{Introduction}

Solid waste management is the most pressing environmental challenge faced by urban and rural areas of Nigeria, with a population exceeding 170 million people. Among several wastes generated by this huge population is agricultural waste. Improper handling of agricultural waste has raised a significant challenge in the past decades. In 2016, agriculture contributed $19.17 \%$ to the gross domestic product (GDP) of Nigeria and it also generated large amount of waste materials. Nigeria is involved in growing and producing many food crops. One of such crops is cassava, a starchy staple food crop which has the ability to resist drought and diseases. In 2012, the production of cassava worldwide was estimated at over 260 million tonnes, with Nigeria being the largest producer, contributing over $20 \%$ of the global production [1,2]. In Nigeria, cassava is mostly produced and processed by small-scale farmers at the family or village level. Cassava provides a reliable and inexpensive source of carbohydrates for people in Sub-Saharan Africa, especially in Nigeria, where its production, processing, and consumption is most predominant and significant on a global scale $[3,4]$. It also provides different job opportunities for both men and women from the production stage until it gets to the final stage. There are indications that the domestic demand for cassava, particularly as a 
staple food, tends to outweigh the demands of the industrial sector. As farmers are unable to meet their demand, some industries are now engaging in the direct production of their cassava requirements.

Globally, $60 \%$ of the cassava produced is mostly used for consumption in numerous forms by humans, while the animal food industry uses about $33 \%$ of the world production. The remaining $7 \%$ is used by industries to produce products such as textiles, paper, organic acids, flavor and aroma compounds, and cassava bagasse [5]. Three main types of residues are generated during the industrial processing of cassava: peels, solids, and wastewater. These wastes are poor in protein content, but their residues are very rich in carbohydrate and are generated in large amounts during the production of 'garri' and cassava flour from the tubers. The cost associated with the handling and disposal of these wastes constitutes a huge financial burden to the cassava-processing industries in most rural regions of the country. As a result of this challenge, most rural cassava processors choose to dispose the cassava-processing wastes generated into the environment. These wastes have been identified to be toxic to the environment $[2,4,6]$.

The technology of processing cassava roots predominantly includes peeling, grating, dewatering, fermenting, drying, frying, etc. The type and composition of the waste depend on the processing method and type of technology used [7]. In most cassava-processing communities, several tonnes of cassava peels are generated as a waste product from the processing activity and are generally considered to contribute largely to environmental pollution [8]. With an expected increase in cassava production, it is also expected that waste generation will continue to rise. Even though cassava peels can be used as feed for livestock, the quantities generated and the remoteness of many of the communities where processing takes place leave behind a lot of waste, which is burnt or left to rot, with many environmental consequences [9]. Tonukari et al. [10] presented a report of a cassava starch production center which produces 100 tons of tubers per day, with an output of about 47 tons of byproducts. This output may cause environmental problems when abandoned in the surroundings of processing plants or carelessly disposed. The basic form of cassava flour production comprises sorting, weighing, peeling, washing, grating, machine/milling, detoxification, dewatering, granulation, drying milling, sieving, and packaging [11,12].

Management of cassava waste varies across several processing centers in the country, and over $55 \%$ of waste generated from its processing is disposed in dump sites. This implies that a great number of cassava processors do not get benefit from the waste they produce [13]. The majority of the cassava peels in Nigeria are abandoned close to the processing site, while some are used for landfilling or burnt. This approach causes a serious threat to the environment and a health hazard to processors and communities [2]. Oparaku et al. [14], from their experiment, expressed that cassava wastes can be used as a biogas substrate, either as a standalone raw material or in combination with livestock manure. Attempts have been made by various researchers to produce products such as organic acid, flavor and aroma compounds, methane and hydrogen gas, enzymes, ethanol, lactic acid, biosurfactant, polyhydroxyalkanoate, essential oils, xanthan gum, and fertilizer from cassava bagasse, peels, and wastewater $[2,5,12,13,15,16]$.

Furthermore, prior studies on cassava waste management $[2,4,13]$ focused on different aspects of cassava waste management; however, there is still a dearth in the literature of studies that combine the potential in the reuse of cassava waste, gender composition of cassava processors in Nigeria, and also factors affecting the willingness to pay for cassava waste management in Ogun State. According to Echebiri and Edaba [17], there is a high positive correlation between the increase of cassava production and the estimated demand for the commodity. It was also found that the waste disposal habits of the people, corruption, work attitude, and inadequate plants and equipment, among others militate against effective waste management in Nigeria [18]. From the foregoing, there is a need for better management and utilization of these waste residues through a better waste management system. It is against this backdrop that this research investigates the potential for an integrated cassava waste management strategy with a focus on Ogun State, Nigeria. Furthermore, this study examined the 
waste management systems presently in use by cassava processors and their willingness to pay for a value-added solid waste management system.

The main objective of this study is to investigate the cassava waste management methods in Ogun State. Other specific objectives of the study are to:

i. find out the method of waste disposal that is adopted by cassava processors in the selected local government areas,

ii. find out what cassava residues are used for in the selected cassava-processing factories,

iii. find out the factors that influence processors' willingness to pay for an improved waste management system, and

iv. investigate if cassava wastes generated in the selected local government areas have the potential for the generation of biofuel.

\section{Materials and Methods}

This study focuses on five local government areas (LGAs) (Yewa North, Odeda, Ijebu North, Ijebu East, and Remo North LGAs) (Figure 1). These local government areas are dominant in processing cassava. A total of 500 questionnaires were administered to selected cassava processors, with 100 questionnaires in each of the LGAs. Figure 2 shows the typical cassava crop harvest while Figure 3 $(\mathrm{a}-\mathrm{c})$ shows the activities in one of the cassava-processing factories. In line with Omilani et al. [2], a survey research design was used for this study as it was appropriate because the nature of the research requires the investigation of the opinions and experiences of a group of people by asking them questions.

\subsection{Sample Size and Sample Technique}

A good representation of the population was chosen from each local government area where cassava processing is prominent for proper evaluation and analysis. The questionnaire was constructed to provide precise and accurate answers through closed-ended questions. The questions were derived from the statement of problem, research questions, research objectives, and hypothesis for testing. Section A dealt with personal data of the respondents, while section B addressed hypothetical questions. The questionnaires were administered to participants that were educated, while those that were not literate had the questionnaires read and interpreted to them in order to get their responses. All the questionnaires administered were retrieved. A structured interview was also used to elicit information from the respondents.

\subsection{Reliability of Instruments}

The reliability test utilized in this research is Cronbach's alpha reliability test. A result obtained for a sample should be of a reliability of 0.70 or even higher before the research instrument can be used. This study makes use of tables, percentages, and various statistical techniques in the presentation and analysis of the data collected at the significance level of $95 \%$; that is, at the $5 \%$ error limit. The data generated through the questionnaire were analyzed through the aid of a computer application, Statistical Packages for Social Sciences (SPSS). In specific terms, the frequency distribution, simple percentage, and mean were deployed in the data analysis. 


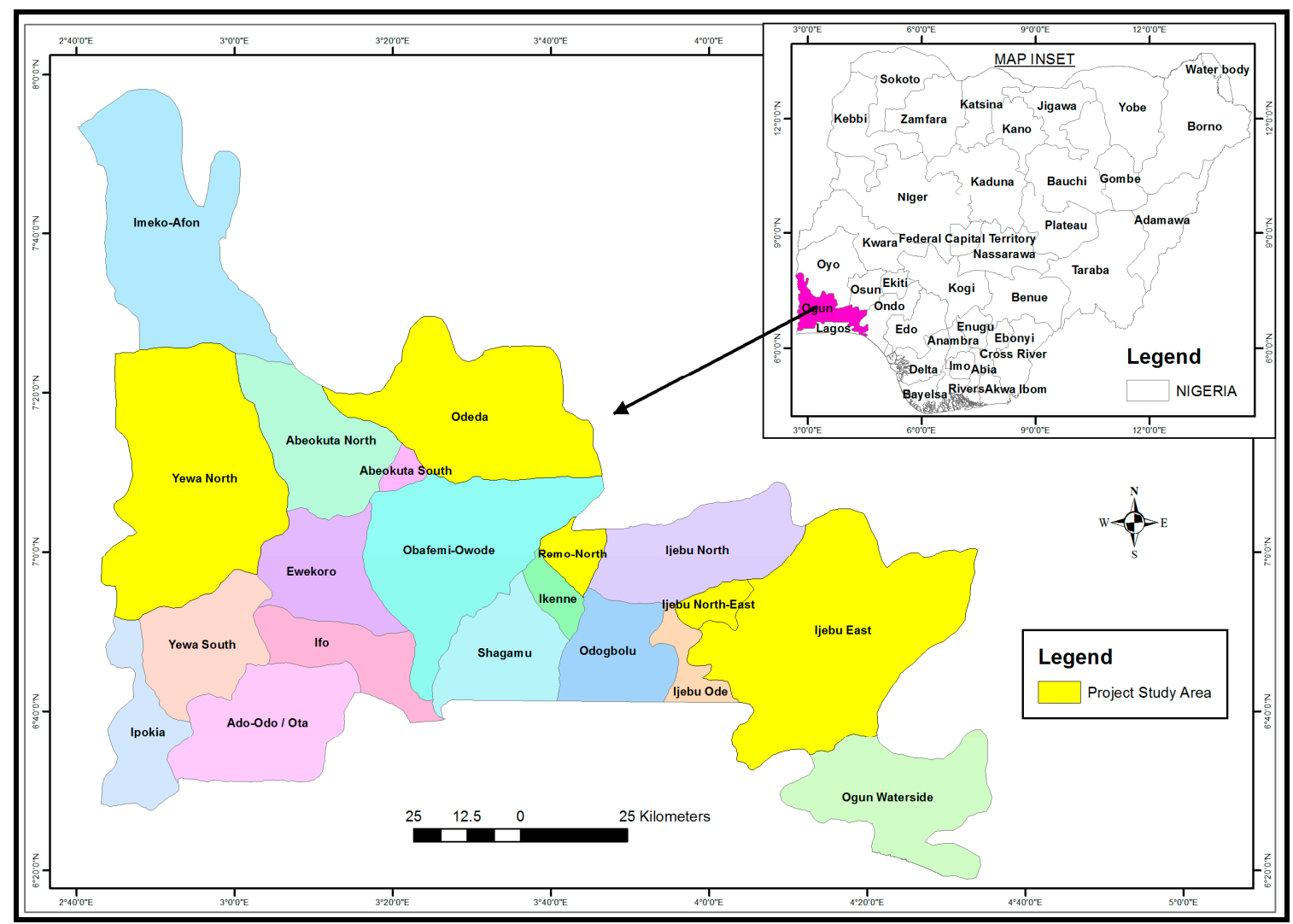

Figure 1. Map of Ogun State showing the study areas in yellow.

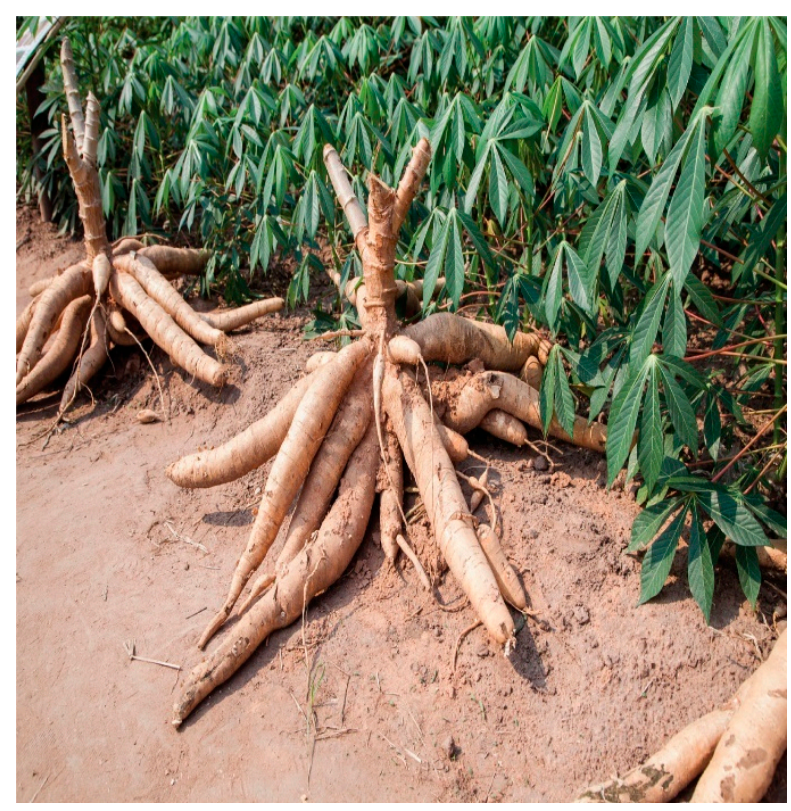

Figure 2. Typical Cassava crop harvest. 


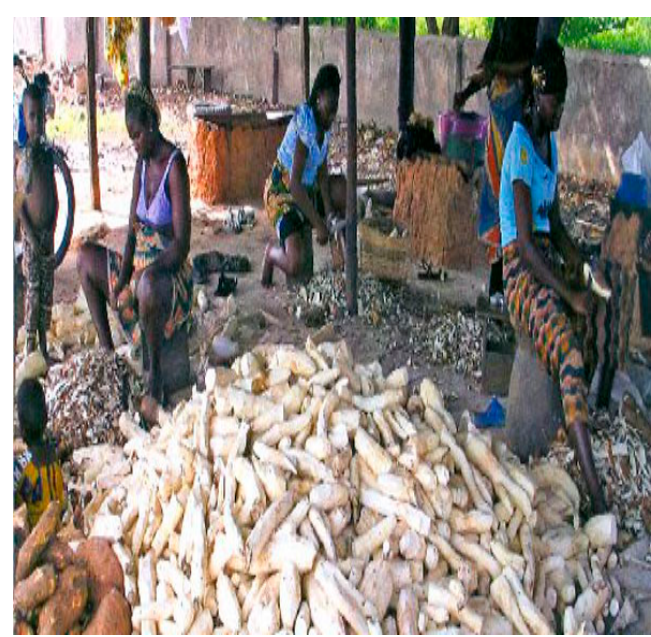

(a)

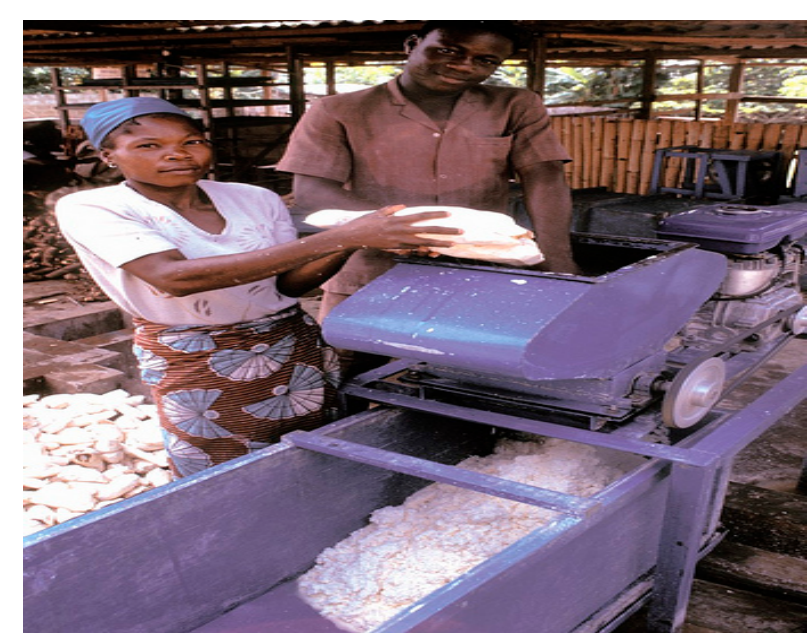

(b)

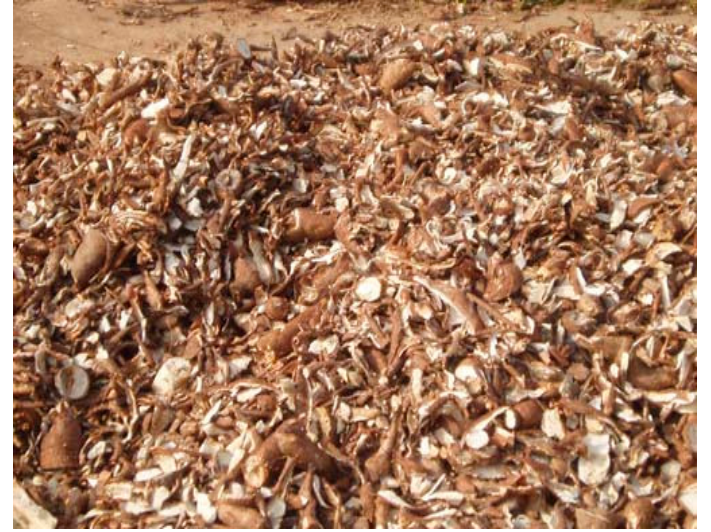

(c)

Figure 3. Activities in the Cassava Processing Factory. (a) Cassava peeling section; (b) Cassava grinding machine in operation; (c) Cassava peel dump site.

\section{Results and Discussion}

Figure 4 shows that the majority of the cassava processors are females, comprising over $70 \%$. This, according to Popescu et al. [19] in their study titled "Managers' gender and SMEs production", implies that the productivity level of local cassava processors is expected to be higher, although this was not explicitly tested for in this study.

Figure 5 shows the age range of the respondents, with $14.2 \%$ of the respondents being between the ages of 20 and 29 years, $34 \%$ between the age of 30 and 39 years, and $30.5 \%$ and $20 \%$ aged between 40 and 49 years and 50 years and above, respectively. From the result in Table 1, it is observed that a great number of cassava processors are in the age range of 30-49 years. 


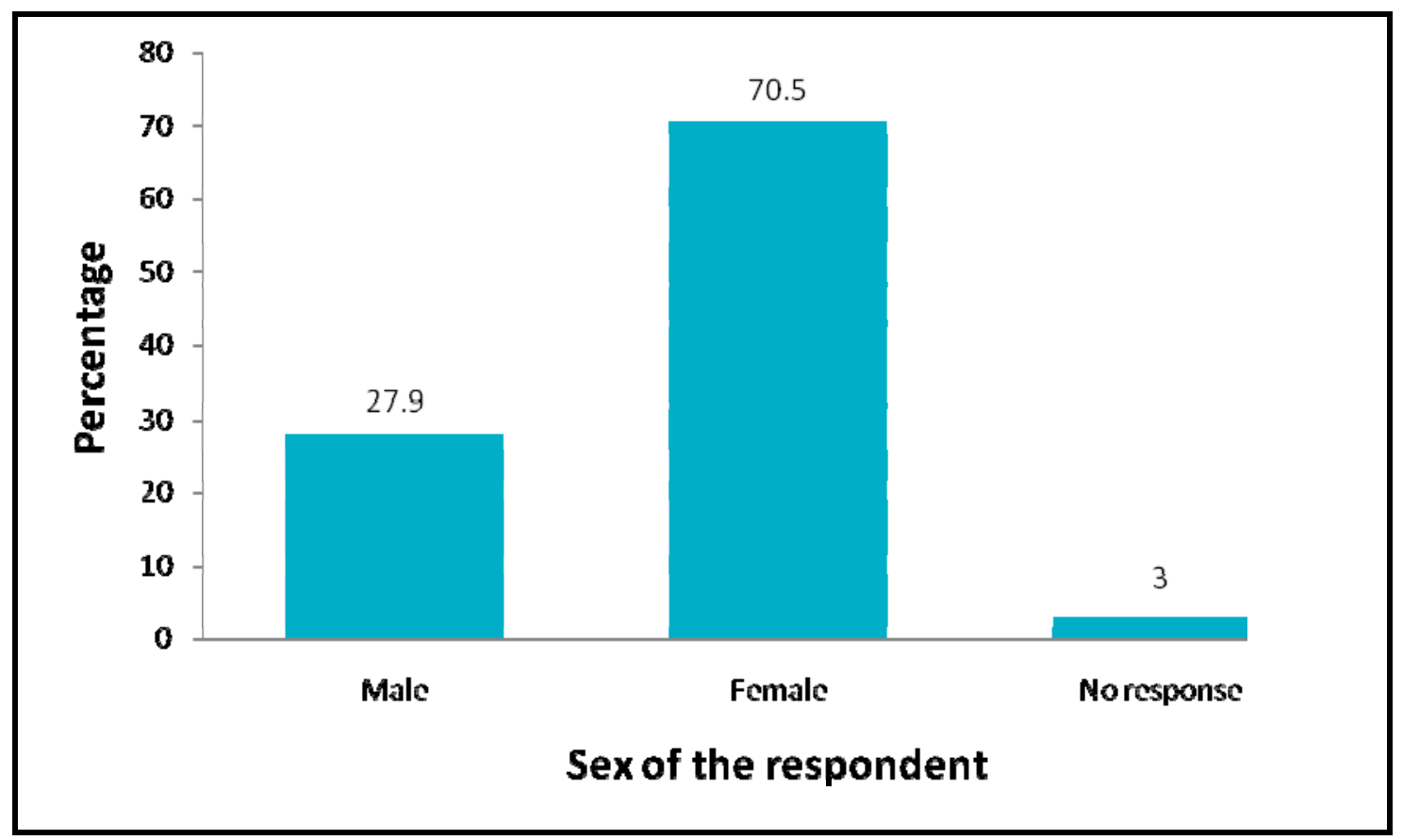

Figure 4. Gender percentage of respondents.

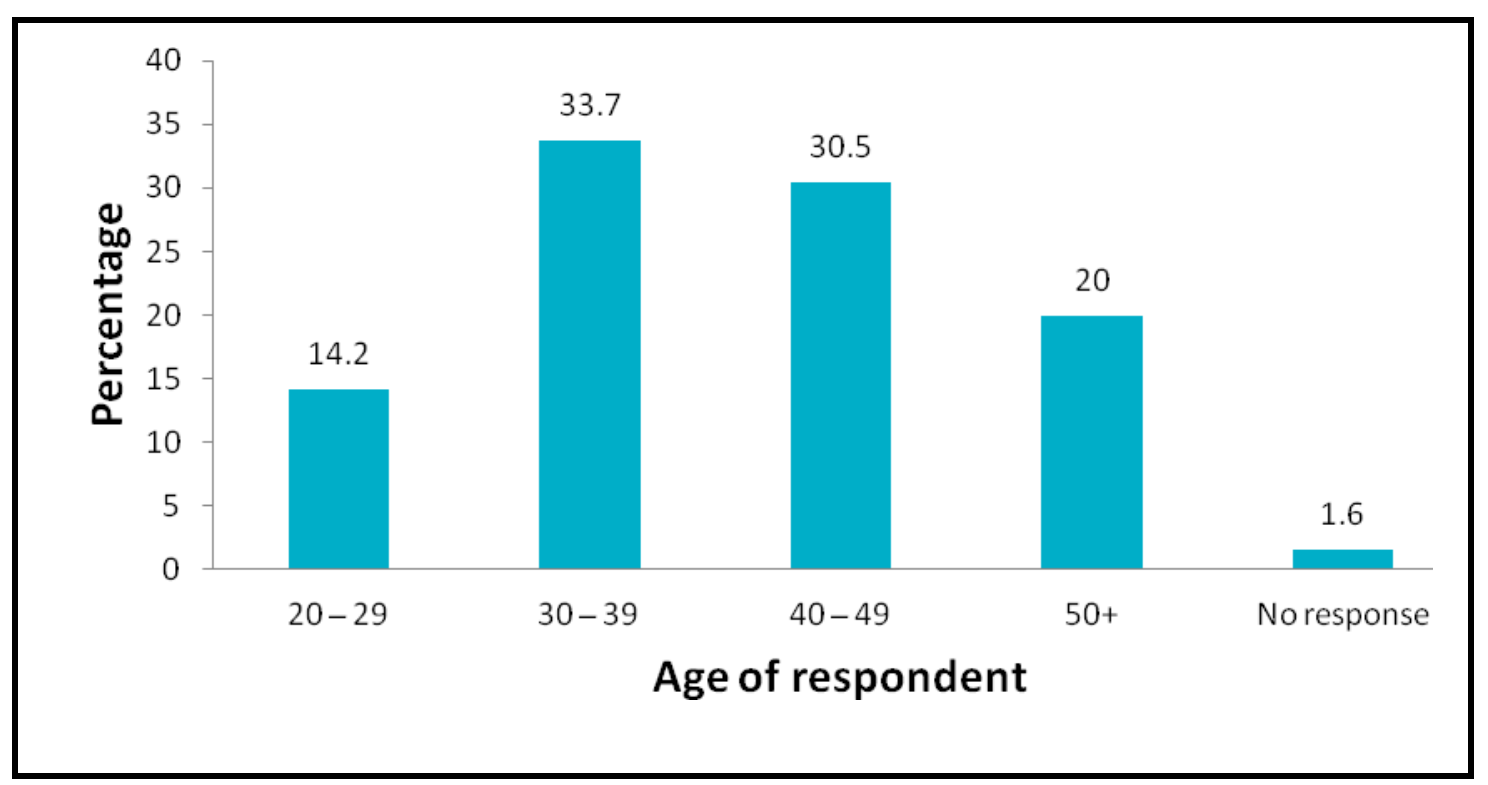

Figure 5. Age variation of respondents. 
Figure 6 shows that the majority of cassava processors are married women who work very hard to earn a living in order to take care of their families.

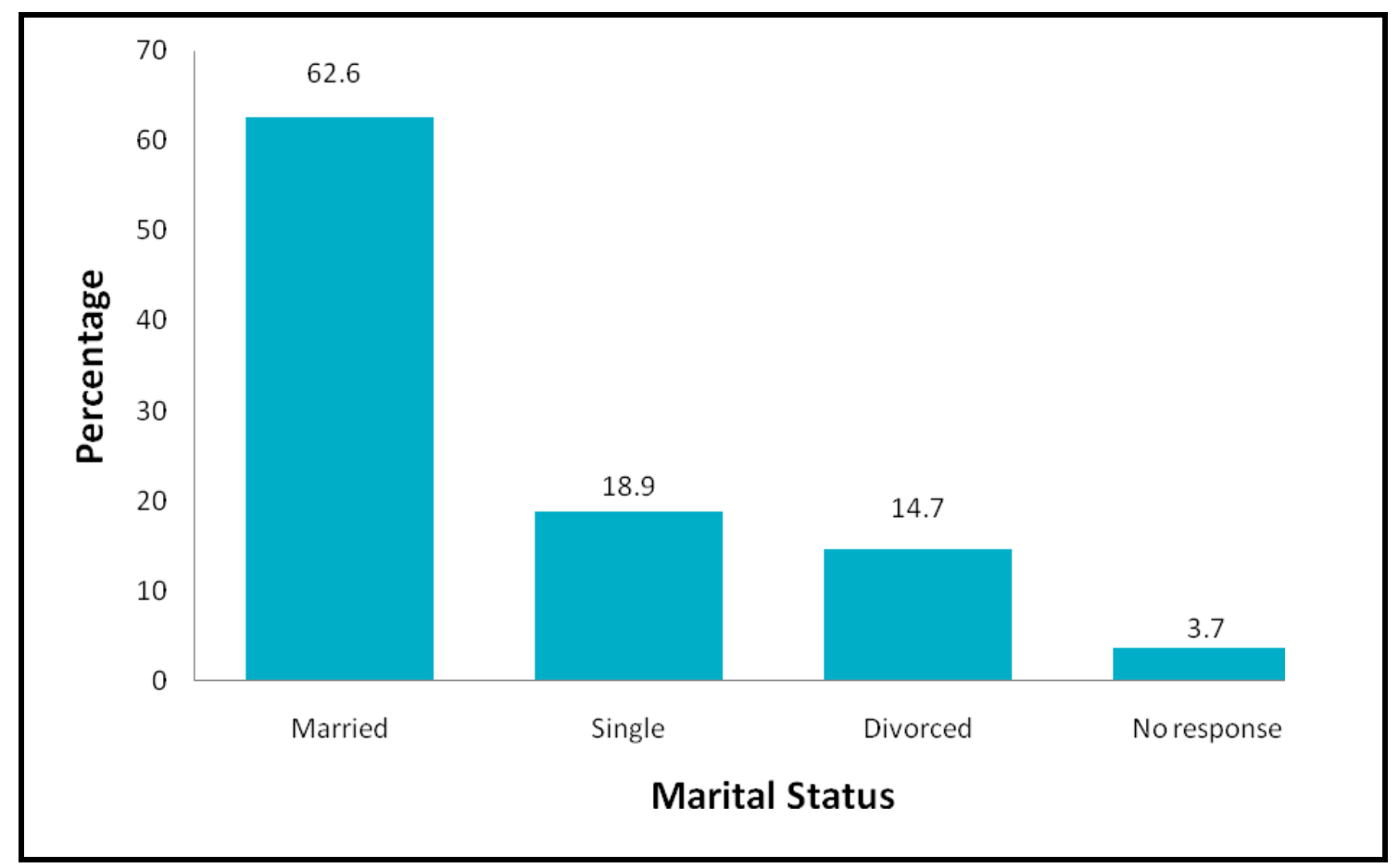

Figure 6. Marital status of respondents.

Figure 7 shows that $46.2 \%$ of respondents have at least a primary or secondary education. However, the results show that the cassava sector does provide a livelihood opportunity for people with no schooling, with $17.9 \%$ of respondents having never attended school.

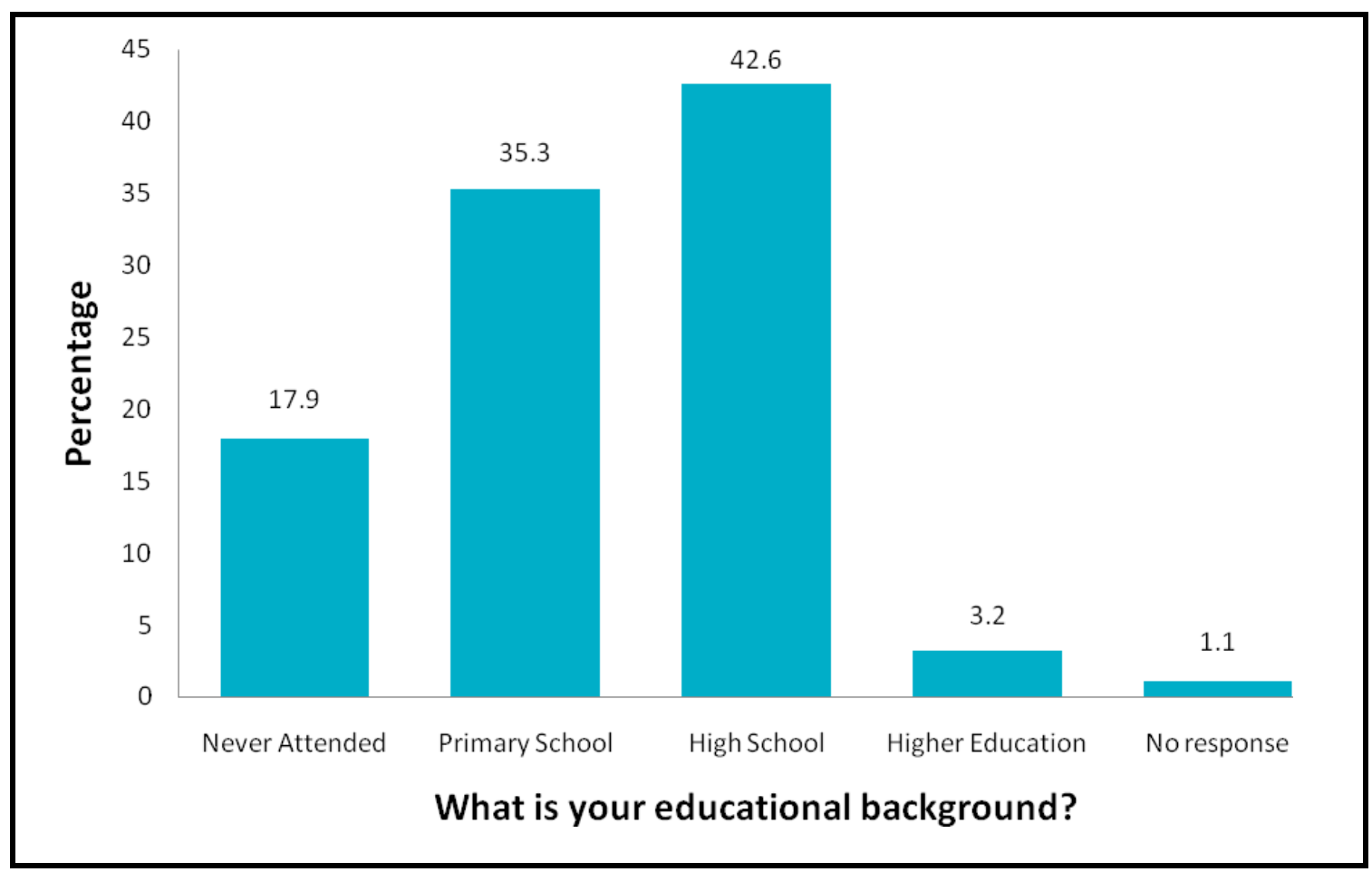

Figure 7. Education level of respondents. 
Figure 8 shows that $55.3 \%$ of respondents have more than 10 years of experience and $34.2 \%$ have more than 5 years of experience in cassava processing. However, the results show that cassava processing does provide new livelihood opportunities for locals, with $9.5 \%$ of respondents having joined this sector in the last 5 years.

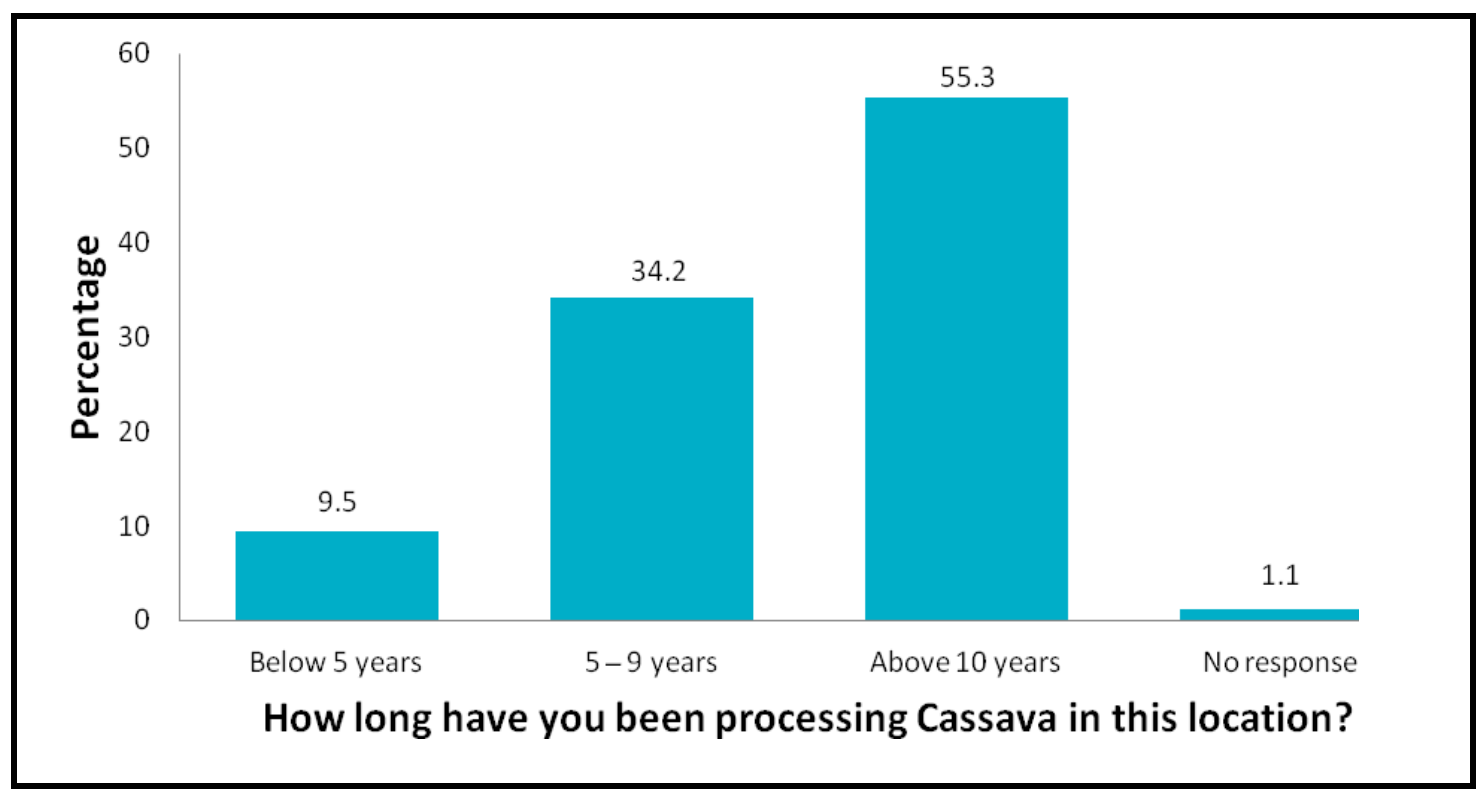

Figure 8. Number of years respondents have worked in cassava processing.

Table 1. Cassava-processing operations in the selected local government areas (LGAs).

\begin{tabular}{|c|c|c|c|c|}
\hline \multicolumn{2}{|c|}{$\begin{array}{l}\text { Major Type of Solid Waste Produced } \\
\text { from the Cassava-Processing Operation }\end{array}$} & Percent & Valid Percent & Cumulative Percent \\
\hline \multirow{5}{*}{ Valid } & Cassava peel and cassava pomace & 86.8 & 86.8 & 86.8 \\
\hline & Cassava peel & 10.5 & 10.5 & 97.3 \\
\hline & Cassava pomace & 1.6 & 1.6 & 98.9 \\
\hline & No response & 1.1 & 1.1 & 100.0 \\
\hline & Total & 100.0 & 100.0 & \\
\hline \multicolumn{5}{|c|}{ How are the cassava solid wastes disposed? } \\
\hline \multirow[t]{4}{*}{ Valid } & Cassava waste dump site & 90.5 & 90.5 & 90.5 \\
\hline & Burnt near the factory & 4.2 & 4.2 & 94.7 \\
\hline & No response & 5.3 & 5.3 & 100.0 \\
\hline & Total & 100.0 & 100.0 & \\
\hline \multicolumn{5}{|c|}{ What do you use cassava residues for? } \\
\hline \multirow[t]{4}{*}{ Valid } & Animal feeds & 97.3 & 97.3 & 97.3 \\
\hline & Fertilizer & 1.6 & 1.6 & 98.9 \\
\hline & No response & 1.1 & 1.1 & 100.0 \\
\hline & Total & 100.0 & 100.0 & \\
\hline \multicolumn{5}{|c|}{ Willingness to pay for an improved waste management system } \\
\hline \multirow[t]{4}{*}{ Valid } & Yes & $74.7\{\mathrm{~F}=87.3 ; \mathrm{M}=12.7\}$ & 74.7 & 74.7 \\
\hline & No & $24.2\{\mathrm{~F}=17.4 ; \mathrm{M}=82.6\}$ & 24.2 & 98.9 \\
\hline & No response & 1.1 & 1.1 & 100.0 \\
\hline & Total & 100.0 & 100.0 & \\
\hline
\end{tabular}

Table 1 shows that over $86 \%$ of the respondents confirmed that cassava peels and cassava pomace are the major solid wastes generated, with $10.5 \%$ indicating that cassava peel is the major solid waste they produce. However, $1.6 \%$ indicated that cassava pomace is the major solid waste they produce. This result indicates that the majority of the cassava-processing units are involved in the production of 'garri' and 'fufu' [20]. Results obtained by Coker et al. [21] showed that the percentage and composition 
of solid waste (peels and bagasse) and liquid waste generated during cassava processing depends on the nature of the final product. The study conducted by Niringiye and Omortor [22] was on factors influencing willingness to pay (WTP) for waste management. They found that the age of the respondents has a negative and significant effect on WTP for waste management in Kampala city in Uganda. Coker et al. [21] conducted a study that focused on evaluating the cassava production activities in six selected cassava-processing sites in Ibadan city. Results showed that the percentage and composition of solid waste (peels and bagasse) and liquid waste generated during cassava processing depends on the nature of the final product. Irene and Richard [23], in their study, focused on the types of waste generated by cassava-processing plants. The survey showed that the wastes generated were cassava peels, fibrous material, chaff, wash water, and liquor. The study did not investigate the methods of waste management adopted.

Table 1 shows that the majority $(90.5 \%)$ of the cassava processors dump the cassava waste generated at the cassava waste dump site. The table also indicates that $4.2 \%$ of the respondents burn the cassava solid waste generated near the factory, which is a major source of environmental pollution. Table 1 indicates that $97.3 \%$ of the respondents that use the cassava residue use it for animal feed or give to those that use them as animal feed. However, $1.6 \%$ of respondents that use the cassava residue use it as fertilizer. Table 1 shows that the majority $(74.7 \%)$ of the respondents are willing to pay for an improved waste management system. The result further shows that $87 \%$ of the respondents who showed interest in paying for an improved waste management system are female. This is in line with the result of Omilani et al. [8]. Their result showed that the majority $(68.73 \%)$ of the respondents who are female cassava processors were willing to pay for a value-added waste management system. The study compared the level of environmental pollution between small-scale cassava-processing firms and large-scale cassava firms. Investigations conducted confirmed that small-scale cassava processing affects the environment more than large-scale processing. Awunyo-Victor et al. [24] further revealed that the significant factors determining households' willingness to pay for improved solid waste management (collection and disposal) are the posted cost of the service, age, educational level, household size, and household monthly expenditure. In addition, cost sharing of waste management is affected by family income. From the study of Oyegbami et al. [25] on the awareness of occupational and environmental hazards associated with cassava processing in south-western Nigeria, it was established that cassava processors were aware of occupational and environmental hazards associated with cassava processing.

\section{Biogas Production Potential}

Table 2 shows the average cassava production capacity for factories in each of the LGAs. From $1000 \mathrm{~kg}$ of cassava, $300 \mathrm{~kg}$ of peel could be produced. Therefore, the weight of cassava peel in each LGA would be the equivalent of the (weight of cassava produced in $\mathrm{kg} \times 300 / 1000$ ). According to Wantanee and Rodtong [26], $1000 \mathrm{~kg}$ of dry cassava tubers could produce $497.01 \mathrm{~L}$ of biogas and $1000 \mathrm{~kg}$ of fresh cassava tubers could produce $235.1 \mathrm{~L}$ of biogas. Therefore, the weight in $\mathrm{kg}$ of cassava peel will produce (weight in $\mathrm{kg} \times 497.01 / 1000)=$ volume in $\mathrm{L}$ of biogas.

Table 2. Biogas production potential from cassava peel.

\begin{tabular}{|c|c|c|c|c|c|}
\hline $\begin{array}{l}\text { Local Government } \\
\text { (5 Factories) }\end{array}$ & Yewa North & Odeda & Ijebu North East & Ijebu East & Remo North \\
\hline $\begin{array}{l}\text { Cassava production } \\
\text { per day }(\mathrm{kg})\end{array}$ & 7500 & 10,000 & 12,000 & 8750 & 7500 \\
\hline $\begin{array}{l}\text { Quantity of cassava } \\
\text { peel per day }(\mathrm{kg})\end{array}$ & 2250 & 3000 & 3600 & 2625 & 2250 \\
\hline $\begin{array}{l}\text { Quantity of biogas } \\
\text { (L/day) }\end{array}$ & $\begin{array}{l}(2250 \mathrm{~kg} \times 497.01) \\
\quad=1,118.273\end{array}$ & $\begin{array}{l}(3000 \mathrm{~kg} \times 497.01) \\
\quad=1,491.030\end{array}$ & $\begin{array}{l}(3600 \mathrm{~kg} \times 497.01) \\
\quad=1,789.236\end{array}$ & $\begin{array}{l}(2625 \mathrm{~kg} \times 497.01) \\
\quad=1,304.651\end{array}$ & $\begin{array}{c}(2250 \mathrm{~kg} \times 497.01) \\
\quad=1,118.273\end{array}$ \\
\hline
\end{tabular}




\section{Conclusions}

The study revealed that there is no proper waste disposal method adopted by cassava processors in the selected LGAs in Ogun State. This is because the wastes generated are not properly disposed of. There was no significant difference in the waste disposal methods as adopted by the LGAs. This is because the majorities of the respondents either use the residues from the cassava processing for feeding their livestock or use them as fertilizer. It is therefore evident that the respondents are not exposed to the income-generating potentials of the cassava wastes. This was based on the responses on the questionnaire served and the focus group discussion. Most of them are local people with limited education.

The study concludes that the major waste is from 'garri' and 'fufu'-processing production. Though the cassava processors have an awareness of the health hazards associated with improper waste management, they prefer to dump the wastes at dump hills or burn them near the factories. The study concludes that majority of the cassava processors are female. Therefore, gender is a major determining factor as it influences the processors' willingness to pay. Also, the majority of the cassava processors do not generate income from the waste generated from the cassava residues.

Finally, the study concludes that based on the quantity of cassava peels generated which are dumped and burnt by the cassava processors in the selected LGAs, there is a huge potential for biogas production from these wastes generated. This biogas can be used as a substitute for the firewood which is currently in use by all the cassava processors.

\section{Recommendations}

From the findings, the study therefore recommends the following:

i. That proper waste disposal methods should be adopted by the cassava processors in Ogun State to minimize pollution and reduce health risks.

ii. There is a need for awareness of the income generation potential of cassava waste among the cassava processors in Ogun State.

iii. It is highly recommended that the waste water generated from cassava processing undergoes proper treatment before it is discharged.

iv. Based on the biogas generation potential of the cassava-processing factories in Ogun State, it is important that this resource be harnessed.

Author Contributions: Conceptualization of the research work came from D.O.O. and T.O.O.; and the methodology adopted was carried out by the authors: D.O.O. and T.O.O. All the authors played a contributing role in the use of the software, and the validation of the work was carefully checked by D.O.O. The formal analysis and investigation was done by D.O.O. Resources and data curation was carried out by D.O.O., and T.O.O. While the writing of original draft preparation was done by D.O.O. Writing-review editing was done by D.O.O. Visualization, supervision and project administration was done by D.O.O.

Funding: This research received no external funding.

Acknowledgments: The authors are grateful to the management of Covenant University for providing an enabling environment in doing the report of this research work. We also appreciate the members of the communities in the selected local government areas for making available information that led to the success of this work and giving access to their communities.

Conflicts of Interest: The authors declare no conflict of interest.

\section{References}

1. Asante-Pok, A. Analysis of Incentives and Disincentives for Cassava in Nigeria; FAO Technical Notes Series; FAO: Rome, Italy, 2013.

2. Omilani, O.; Abass, A.; Okoruwa, V.O. Willingness to Pay for Value-Added Solid Waste Management System among Cassava Processors in Nigeria. 2015. Available online: www.tropentag.de/2015/proceedings/ node515.html (accessed on 22 May 2018). 
3. Westby, A. Cassava Utilization, Storage and S mall-scale Processing. In Cassava Biology, Production and Utilization; Hillock, R., Thresh, J., Bellotti, A.C., Eds.; CABI Publishing: Wallingford, UK, 2008.

4. Olukanni, D.O.; Agunwamba, J.C.; Abalogu, R.U. Interaction between suspended and settled solid particles in cassava waste water. Sci. Res. Essay 2013, 8, 414-424.

5. Pandey, A.; Soccol, C.R.; Nigam, P.; Soccol, V.T.; Vandenberghe, L.P.; Mohan, R. Biotechnological potential of agro-industrial residues. II: Cassava bagasse. Bioresour. Technol. 2000, 74, 81-87. [CrossRef]

6. Barros, F.; Ana, P.D.; Júnio, C.; Gláucia, M. Potential Uses of Cassava Wastewater in Biotechnological Processes. In Agriculture Issues and Policies: Cassava Farming, Uses and Economic Impact; Pace, C.M., Ed.; NOVA Science Publishers Inc.: New York, NY, USA, 2012; Chapter 2; pp. 33-54. ISBN 978-1-61209655-1.

7. Osunbitan, J.A. Short term effects of Cassava processing waste water on some chemical properties of loamy sand soil in Nigeria. J. Soil Sci. Environ. Manag. 2012, 3, 164-171.

8. FAO (Food and Agricultural Organization) of United Nations. Annual Statistics; FAO: Rome, Italy, 2004.

9. Eze, J.I. Converting Cassava (Manihot spp) Waste from Gari Processing Industry to Energy and Bio-Fertilizer. Glob. J. Res. Eng. 2010, 10, 113-117.

10. Tonukari, N.J.; Ezedom, T.; Enuma, C.C.; Sakpa, S.O.; Avwioroko, O.J.; Eraga, L.; Odiyoma, E. White Gold: Cassava as an Industrial Base. Am. J. Plant Sci. 2015, 6, 972-979. [CrossRef]

11. Dada, A.D.; Afolabi, O.O.; Siyanbola, W.O. Harnessing Science and Technology for Cassava Productivity and Food Security in Nigeria. In Proceedings of the Portland International Conference on Management of Engineering \& Technology, Portland, OR, USA, 2-6 August 2009.

12. Aro, S.O.; Aletor, V.A.; Tewe, O.O.; Agbede, J.O. Nutritional potentials of cassava tuber wastes: A case study of a cassava starch processing factory in south-western Nigeria. Livest. Res. Rural Dev. 2010, 22, 1-11.

13. Sackey, I.S.; Bani, R.J. Survey of waste management practices in cassava processing to gari in selected districts of Ghana. J. Food Agric. Environ. 2007, 5, 325-328.

14. Oparaku, N.F.; Ofomatah, A.C.; Okoroigwe, E.C. Biodigestion of cassava peels blended with pig dung for methane generation. Afr. J. Biotechnol. 2013, 12, 5956-5961. [CrossRef]

15. Olukanni, D.O.; Aremu, O.D. Provisional Evaluation of Composting as Priority Option for Sustainable Waste Management in South-West Nigeria. Pollution 2017, 3, 417-428.

16. Oresanya, O.O.; Olukanni, D.O. The evolution of solid waste management in Lagos State, Nigeria. A glance at the world. Waste Manag. 2017, 66, 1-3.

17. Echebiri, R.N.; Edaba, M.E. Production and Utilization of Cassava in Nigeria: Prospects for Food Security and Infant Nutrition. Prod. Agric. Technol. 2008, 4, 38-52.

18. Onu, B.; Surendran, S.S.; Price, T. Impact of Inadequate Urban Planning on Municipal Solid Waste Management in the Niger Delta Region of Nigeria. J. Sustain. Dev. 2014, 7, 27-45. [CrossRef]

19. Popescu, A.M.; Alecxandrina, D.; Popescu, T. The impact of gender difference at Romanian small and medium enterprises (SME) management level, analyzed by organizational citizenship behavior. Eur. J. Hum. Soc. Sci. 2013, 27, 1390-1406. [CrossRef]

20. Adebayo, K.; Anyanwu, A.C.; Osiyale, A.O. Perception of Environmental Issues by Cassava Processors in Ogun State, Nigeria-Implications for Environmental Extension Education. J. Ext. Syst. 2003, 19, 103-112.

21. Coker, A.; Achi, C.; Sridhar, M.K. Utilization of Cassava Processing Waste As A Viable And Sustainable Strategy For Meeting Cassava Processing Energy Needs: Case Study From Ibadan City, Nigeria. In Proceedings of the Thirtieth International Conference on Solid Waste Technology and Management, Philadelphia, PA, USA, 3-6 April 2010.

22. Niringiye, A.; Omortor G., D. Determinants of Willingness to Pay for Solid Waste Management in Kampala City. Curr. Res. J. Econ. Theory 2010, 2, 119-122.

23. Olukanni, D.O.; Adeleke, J.O.; Aremu, D.D. A Review of Local Factors affecting Solid Waste Collection in Nigeria. Pollution 2016, 2, 339-356.

24. Awunyo-Vitor, D.; Ishak, S.; Jasaw, G.S. Urban Households' Willingness to Pay for Improved Solid Waste Disposal Services in Kumasi Metropolis, Ghana. Urban Stud. Res. 2013, 2013, 2-8. [CrossRef] 
25. Oyegbami, A.; Oboh, G.; Omueti, O. Cassava processors' awareness of occupational and environmental hazards associated with cassava processing in South-Western Nigeria. Afr. J. Food Agric. Dev. 2010, 10, 2177-2186.

26. Wantanee, A.; Rodtong, S. Laboratory Scale Experiments for Biogas Production from Cassava Tubers. Presented at the Joint International Conference on "Sustainable Energy and Environment", Hua Hin, Thailand, 1-3 December 2004. 